\title{
NUMERICAL SIMULATION OF SEPARATING FLOW AROUND A BODY USING ARTIFICIAL COMPRESSIBILITY METHOD
}

\author{
擬似圧縮性法による物体周りの剝離流れの数值解析 \\ Hiroto KATAOKA* and Minoru MIZUNO** \\ 片岡浩人, 水野 稔
}

\begin{abstract}
An algorithm based on the artificial compressibility method is tested for the computation of separating flow around a body. A third-order upwind differencing scheme is used to compute convective terms and a fourth-order damping term is added to the pressure equation to avoid unphysical oscillations. The optimal parameter values are examined through a series of two-dimensional laminar flow computations over a circular cylinder. The results indicate the optimal value for the artificial compressibility parameter can be decided with the physical time step size. Then three dimensional flow computations around a square cylinder at the Reynolds number 22,000 are presented and the results are compared with experimental and other computational results. Though present computations are laminar, the computed results show better agreement with the experimental data.
\end{abstract}

Keywords : artificial compressibility method, separating flow computation, square cylinder, multiblock structured grid system 擬似圧縮性法、剥離流れ解析、正方形角柱、マルチブロック構造格子

\section{Introduction}

The flow around a bluff body, like a building structure, usually gets separated. Those separations are determined by pressure distributions around a body and its geometry. For simulating flows separating around a body, it is essential to predict precise pressure distributions as well as to achieve a high grid resolution around a body.

As for the pressure distributions, flow computations in the building engineering field usually assume that the flow is incompressible, no equation for the pressure is provided explicitly. Such computational algorithms, as MAC ${ }^{1)}$, HSMAC $^{2)}$ and SIMPLE $^{3}$ ), introduce a Poisson equation for the pressure or for the pressure correction. With the absence of the time derivative of pressure, the Poisson equation becomes elliptic and it must be solved with an iterative method.

The use of a usual single structured grid system causes considerable difficulties when one is to generate a high resolution grid around a geometrically complex building. To get over those difficulties the domain decomposition technique has been developed, that is to divide a computational domain into several sub-domains to solve flow fields separately. This domain decomposition technique needs to take careful treatments for solving the Poisson equation for pressure at the boundary where sub-domains are connected. As stated above, an iterative manner must be taken, and for keeping a consistent pressure field it is required to exchange pressure values among sub-domains at certain iteration intervals. Suwa et al. ${ }^{4)}$ reported that their computations, based on overlapping grids and SIMPLE algorithm, resulted in discrepant pressure distributions from one with a single grid system when an insufficient data exchange rate was taken. Meanwhile, the authors ${ }^{5)}$ presented a general multiblock solver and showed its computed results of incompressible flows about geometrically complex structures. Instead of solving the Poisson equation for pressure, the solver is based on the idea of artificial compressibility.

The artificial compressibility method was first introduced by Chorin $\left.{ }^{6}\right)$ for computing steady-state incompressible flows. Lately this method has been extended to time-depending flow computations ${ }^{7)-8)}$ by adopting the idea of dual time stepping i.e., physical time and pseudo-time stepping. Ohnishi et al. ${ }^{9)}$ deduced an optimal value for the artificial compressibility parameter by comparing with HSMAC. As all variables are obtained by a time marching procedure with the artificial compressibility method, there is no need for solving any additional equation for pressure.

* Technical Research Institute, Obayashi Corporation

(料大林組技術研究所

** Prof., Dept. of Environmental Engineering, Faculty of Engineering, Osaka Univ., 大阪大学工学部環境工学科 教授・工博 Dr. Eng. 
Since Lyn ${ }^{10)}$ provided detailed experimental data at Reynolds number 22,000, many researchers have computed the flow around a square cylinder. Murakami and Mochida ${ }^{11)}$ reported that their own three-dimensional LES computation based on the Smagorinsky type SGS model showed better agreements than other results from Reynolds-averaged (RANS) turbulence models. Lately they have computed with several types of Dynamic SGS models ${ }^{12}$ ) and showed remarkable improvements of predictions, especially the sizes of the recirculation region formed behind the cylinder coincide well with Lyn's data ${ }^{10}$ ). On the contrary, Ferziger ${ }^{13)}$ stated that details of the turbulence are not so important for the flow computation around a bluff body. If this is the case, computing the flow around a square cylinder without using turbulence models makes sense and comparing results with experimental data or other computed results yield an assessment for the artificial compressibility method.

In the following sections, equations of the artificial compressibility based on the generalized coordinate system are given and its numerical schemes are explained. Once the numerical method has been established, the optimal value for the artificial compressibility parameter is investigated throughout a series of two-dimensional flow computations over a circular cylinder. Finally three-dimensional flow computations over a square cylinder at Reynolds number 22,000 are shown as benchmark computations of the separating flow. Compared with reported computational results and experimental data, the capability for capturing separations by the artificial compressibility method is tested. Since this work is mainly focused on verifying the artificial compressibility method, any turbulence models are not used. As the authors reported ${ }^{5)}$, there are no difficulties in introducing turbulence models to the flow solver presented here.

\section{Governing Equations}

With the idea of artificial compressibility, the governing equations for incompressible laminar flows are derived as follows;

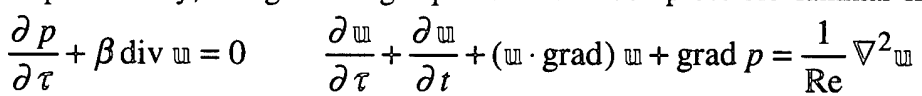

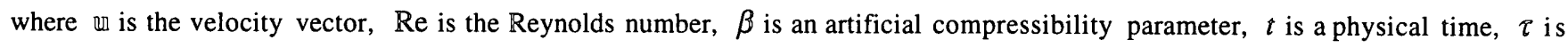
a pseudo-time and $p$ denotes the pressure divided by the fluid's density respectively.

Generalized coordinates are used in the form $\xi=(x, y, z, t) \quad \eta=(x, y, z, t) \quad \zeta=(x, y, z, t)$ resulting in the system equation as;

$$
\begin{aligned}
& \frac{\partial \hat{Q}}{\partial \tau}+I_{m} \frac{\partial \hat{Q}}{\partial t}=\hat{R} \quad \hat{R}=-\frac{\partial\left(\hat{E}_{c}-\hat{E}_{v}\right)}{\partial \xi}-\frac{\partial\left(\hat{F}_{c}-\hat{F}_{v}\right)}{\partial \eta}-\frac{\partial\left(\hat{G}_{c}-\hat{G}_{v}\right)}{\partial \zeta} \quad \hat{Q}=\frac{1}{J} Q=\frac{1}{J}\left[\begin{array}{c}
p \\
u \\
v \\
w
\end{array}\right] \quad I_{m}=\left[\begin{array}{llll}
0 & 0 & 0 & 0 \\
0 & 1 & 0 & 0 \\
0 & 0 & 1 & 0 \\
0 & 0 & 0 & 1
\end{array}\right] \\
& \hat{E}_{c}^{i}=\left[\begin{array}{c}
\beta \hat{U}^{i} \\
\hat{\xi}^{i}{ }_{x} p+\hat{U}^{i} u+\hat{\xi}^{i}{ }_{t} u \\
\hat{\xi}^{i}{ }_{y p} p+\hat{U}^{i} v+\hat{\xi}^{i}{ }_{t} v \\
\hat{\xi}^{i}{ }_{z} p+\hat{U}^{i} w+\hat{\xi}^{i}{ }_{t} w
\end{array}\right] \quad \hat{E}^{i}{ }_{v}=\frac{2}{\operatorname{Re}}\left[\begin{array}{c}
0 \\
\hat{\xi}^{i}{ }_{x} S_{x x}+\hat{\xi}^{i}{ }_{y} S_{y x}+\hat{\xi}^{i}{ }_{z} S_{z x} \\
\hat{\xi}^{i}{ }_{x} S_{x y}+\hat{\xi}^{i}{ }_{y} S_{y y}+\hat{\xi}^{i}{ }_{z} S_{z y} \\
\hat{\xi}^{i}{ }_{x} S_{x z}+\hat{\xi}^{i}{ }_{y} S_{y z}+\hat{\xi}^{i}{ }_{z} S_{z z}
\end{array}\right] \quad \hat{E}^{i}=\hat{E}, \hat{F}, \hat{G} \quad \text { for } i=1,2,3 \\
& \hat{\xi}_{x}^{i}=\frac{\xi^{i} x}{J}=\frac{1}{J} \frac{\partial \xi^{i}}{\partial x} \quad \hat{\xi}_{y}^{i}=\frac{\xi^{i} y}{J}=\frac{1}{J} \frac{\partial \xi^{i}}{\partial y} \quad \hat{\xi}_{z}^{i}=\frac{\xi_{z}^{i}}{J}=\frac{1}{J} \frac{\partial \xi^{i}}{\partial z} \quad \hat{\xi}_{t}^{i}=\frac{\xi^{i} t}{J}=\frac{1}{J} \frac{\partial \xi^{i}}{\partial t} \quad \xi^{i}=\xi, \eta, \zeta \quad \text { for } i=1,2,3
\end{aligned}
$$

where $Q$ is a variable vector, $\hat{E}^{i}{ }_{c}$ and $\hat{E}^{i}{ }_{v}$ are the generalized convective and viscous flux vectors and $I_{m}$ is a modified identity matrix. The symbol $\wedge$ represents a value which is scaled by the Jacobian of the transformation $J$. The scaled contravariant velocity and components of strain rate tensor are defined as follows;

$$
\hat{U}^{i}=\frac{U^{i}}{J}=\hat{\xi}^{i}{ }_{x} u+\hat{\xi}^{i}{ }_{y} v+\hat{\xi}^{i}{ }_{z} w \quad U^{i}=U, V, W \quad \text { for } i=1,2,3(5) \quad S_{x_{i} x_{j}}=\frac{1}{2}\left(\frac{\partial u_{j}}{\partial x_{i}}+\frac{\partial u_{i}}{\partial x_{j}}\right) \begin{gathered}
u_{i}=u, v, w \\
x_{i}=x, y, z
\end{gathered} \text { for } i=1,2,3(6)
$$

According to Rogers and $\mathrm{Kwak}^{8)}$, the Jacobian matrix $\hat{M}^{i}$ of the convective flux vector $\hat{E}_{c}^{i}$ can be diagonalized as follows;

$$
\begin{aligned}
& \frac{\partial \hat{E}_{c}^{i}}{\partial Q}=\hat{M}^{i}=X^{i} \hat{\Lambda}^{i} X^{i-1} \\
& \hat{c}^{i}=\sqrt{\left(\hat{U}^{i}+\hat{\xi}_{t}^{i} / 2\right)^{2}+\beta\left(\hat{\xi}^{i} x^{2}+\hat{\xi}^{i} y^{2}+\hat{\xi}^{i} z^{2}\right)} \\
& \hat{\Lambda}^{i}=\operatorname{diag}\left[\hat{\lambda}_{1}^{i}, \hat{\lambda}_{2}^{i}, \hat{\lambda}_{3}^{i}, \hat{\lambda}_{4}^{i}\right] \quad \hat{\lambda}_{1}^{i}=\hat{\lambda}_{2}^{i}=\hat{U}^{i}+\hat{\xi}^{i}{ }_{t} \quad \hat{\lambda}_{3}{ }_{3}=\hat{U}^{i}+\hat{\xi}_{t}^{i} / 2+\hat{c}^{i} \quad \hat{\lambda}_{4}^{i}=\hat{U}^{i}+\hat{\xi}^{i}{ }_{t} / 2-\hat{c}^{i}
\end{aligned}
$$

where $\hat{\lambda}_{\ell}^{i}$ are the eigenvalues of $\hat{M}^{i}$ and $\hat{c}^{i}$ denotes the scaled artificial speed of sound. Equation (8) leads that the pressure wave travels at a finite speed which differs according to the size of local velocity and metrics. 


\section{Numerical Method}

\subsection{Spatial Discretization}

To obtain solutions which fulfill the conservation laws, a finite volume method is applied. Physical variables are defined at the intersection of grid lines. Details of the definition of a control volume and ways for computing metrics and Jacobian can be found in the authors' paper ${ }^{5}$ )

Physical variables at the node-centers (with indexes $i+1 / 2$ and $i-1 / 2$ ) are given by averaging grid points' values, and non-linear terms are approximated by a fourth-order central differencing plus a fourth-order damping term,

$$
(\mathbf{u} \hat{U})_{i+1 / 2}=\frac{1}{12} \hat{U}_{i+1 / 2}\left(-\mathbf{u}_{i+2}+7 \mathbf{u}_{i+1}+7 \mathbf{u}_{i}-\mathbf{u}_{i-1}\right)-\frac{\alpha}{12}\left|\hat{U}_{i+1 / 2}\right|\left(-\mathbf{u}_{i+2}+3 \mathbf{u}_{i+1}-3 \mathbf{u}_{i}+\mathbf{u}_{i-1}\right)
$$

where $\alpha$ is a parameter for controlling the size of artificial dissipation term. Equation (10) becomes Kawamura-Kuwahara scheme ${ }^{14)}$ when $\alpha$ is set as 3 , and UTOPIA scheme ${ }^{15)}$ with its vale of 1 . Since there is no diffusive term for the pressure, an oddeven decoupling of the pressure field may occur. To avoid unphysical pressure oscillations, a fourth-order damping term is added also to the pressure equation, in the same manner as Equation (10).

$$
(\beta \hat{U})_{i+1 / 2}=\beta \hat{U}_{i+1 / 2}-\frac{\alpha}{12}\left(\hat{c}+\left|\hat{U}+\hat{\xi}_{t} / 2\right|\right)_{i+1 / 2}\left(-p_{i+2}+3 p_{i+1}-3 p_{i}+p_{i-1}\right)
$$

\subsection{Time Derivatives}

Taking a first-order explicit formula for the pseudo-time derivatives and a first or second-order implicit for the physical time derivatives, Equation (2) yields following discretized equations

$$
\begin{array}{cl}
\left(\frac{1}{\Delta \tau}+\frac{I_{m}}{\Delta t}\right)\left(Q^{n+1, m+1}-Q^{n+1, m}\right)=J \hat{R}^{m}-\frac{I_{m}}{\Delta t}\left(Q^{n+1, m}-Q^{n}\right) & : \text { first order } \\
\left(\frac{1}{\Delta \tau}+\frac{3 I_{m}}{2 \Delta t}\right)\left(Q^{n+1, m+1}-Q^{n+1, m}\right)=J \hat{R}^{m}-\frac{I_{m}}{2 \Delta t}\left(3 Q^{n+1, m}-4 Q^{n}+Q^{n-1}\right) & : \text { second order }
\end{array}
$$

where the superscripts $n$ and $m$ denote the quantities at physical time level $t=n \Delta t$ and pseudo-time level $\tau=m \Delta \tau$, respectively. These relations can be simplified with the modified residual $R^{\prime m}$ as;

$$
Q^{n+1, m+1}=Q^{n+1, m}+\Delta \tau R^{\prime m}
$$

The pseudo-time step size $\Delta \tau$ has no physical meanings, hence, it is possible to take arbitrary values. In fact, Rogers and Kwak ${ }^{7), 8)}$ set its nondimensional size as $10^{12}$ while Ohnishi et. al. ${ }^{9)}$ as $0.002 \sim 0.01$. Here the authors relate it to the artificial speed of sound because with the artificial compressibility approach the pressure travels at a finite speed. The pseudo-time step size $\Delta \tau$ is computed locally with a cell-Courant number CFL as,

$$
\Delta \tau=\mathrm{CFL} \times \frac{4}{J\left(\hat{\gamma}^{\xi}+\hat{\gamma}^{\eta}+\hat{\gamma}^{\zeta}\right)} \quad \hat{\gamma}^{i}=\left|\hat{U}^{i}+\frac{1}{2} \hat{\xi}^{i}\right|+\hat{c}^{i} \quad \hat{\gamma}^{i}=\hat{\gamma}^{\xi}, \hat{\gamma}^{\eta}, \hat{\gamma}^{\zeta} \quad \text { for } i=1,2,3
$$

With this definition, the pseudo-time step size is indirectly connected with the artificial compressibility parameter. Then the only remaining parameter which can take any arbitrary value is the artificial compressibility parameter.

To integrate Equation (13) in pseudo-time, an explicit five-stage Runge Kutta time-stepping scheme ${ }^{16)}$ is used.

\subsection{Inflow and Outflow Boundary Conditions}

For the inflow and outflow boundaries, the characteristic approach presented by Rogers and $\mathrm{Kwak}^{8)}$ is taken. Considering steady state in the pseudo-time, setting velocities as those of the free stream at the inflow, and setting the pressure as the free stream one at the outflow boundary, following boundary conditions are provided as follows;

$$
\begin{array}{lll}
\text { inflow : } & p_{\text {boundary }}=p_{\text {interior }}-\frac{\beta}{\hat{\lambda}_{k}}\left(\hat{U}_{\text {interior }}-\hat{U}_{\text {boundary }}\right) & \hat{\lambda}_{k}=\hat{\lambda}_{3} \text { for } \hat{U}>0, \quad \hat{\lambda}_{k}=\hat{\lambda}_{4} \text { for } \hat{U}<0 \\
\text { outflow : } & u_{i \text { boundary }}=u_{i \text { interior }}-\frac{\hat{\xi}_{x_{i}}}{\hat{\xi}_{x}{ }^{2}+\hat{\xi}_{y}{ }^{2}+\hat{\xi}_{z}{ }^{2}} \frac{\hat{\lambda}_{k}}{\beta}\left(p_{\text {interior }}-p_{\text {boundary }}\right) & \hat{\lambda}_{k}=\hat{\lambda}_{4} \text { for } \hat{U}>0, \quad \hat{\lambda}_{k}=\hat{\lambda}_{3} \text { for } \hat{U}<0
\end{array}
$$

\section{Examination of the Optimal Parameter Value}

The authors define the optimal parameter as the value which provides faster convergence in the pseudo-time step iterations. To examine the optimal parameter value, a series of two-dimensional laminar flow computations around a circular cylinder was conducted. The whole computational domain was set $17 D \times 15 D$ where $D$ is a diameter and was divided into 5 blocks. Figure 1 shows the grid system close to a cylinder. The cylinder is surrounded by an O-type grid system consisting of $193 \times 41$ grid points and the distance between the surface of cylinder and the first interior grid point was set as $0.001 D$. The rest of the domain is covered by 4 rectangular 
grid systems and the total number of grid points was 14,898. We took a no-slip condition for the surface of cylinder, a free-slip condition for side boundaries and Equation (16) for the inflow and outflow boundaries respectively. The parameter for artificial dissipation term $\alpha$ was set as 3. The physical time derivatives are treated as first-order implicit and the cell-Courant number for Equation (14) was set as 1.5 .

Each computation was conducted along with the following processes; 1) Set a uniform flow distribution $\mathbb{u}=\left(u_{0}, 0\right)$ at every grid point as an initial condition. 2) Compute the flow up to $t u_{0} / D=30$. At each physical time step, the pseudo-time iterations were carried out until the maximum residual $\Delta \tau\left|R^{\prime}\right|$ became less than $10^{-4}$ while the maximum iteration cycle was set as 500 . 3) Then compute one physical time step with 500 pseudo-time iterations. The maximum value of $\Delta \tau\left|R^{\prime}\right|$ was recorded at each iteration to compare its convergence history.

In Figures $2 \mathrm{a} \sim 2 \mathrm{f}$, the convergence histories of $\Delta \tau\left|R^{\prime}\right|$ versus the pseudotime iterations are shown. The Reynolds number is computed as $\operatorname{Re}=u_{0} D / v$.

Figures $2 \mathrm{a} \sim 2 \mathrm{c}$ show the effects of the artificial compressibility parameter $\beta$ to the convergence histories with different physical time step sizes at the Reynolds number 500. In the case of 0.01 physical time step $\Delta t u_{0} / D$ (Fig, 2a), $\beta$

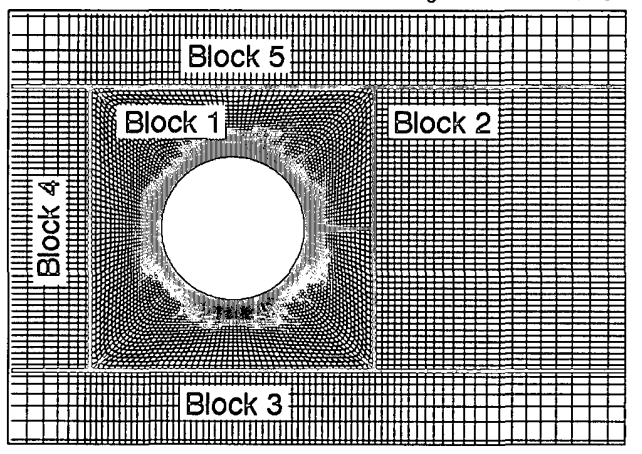

Figure 1 Grid system around a circular cylinder of 100 shows the fastest convergence. The smaller values of $\beta$ provide slower convergence and the $\beta$ of 10,000 shows the worst. When the physical time step $\Delta t u_{0} / D$ is increased to 0.05 (Fig. 2b), $\beta$ of 20 shows the smallest resiudual value at the iteration cycle of 500 and $\beta$ of 10 and 20 for 0.1 of $\Delta t u_{0} / D$ (Fig. 2c). Throughout these comparisons it can be said that the optimal value of $\beta$ depends on the size of physical time step $\Delta t$.

Figures $2 \mathrm{~b}, 2 \mathrm{~d}$ and $2 \mathrm{e}$ show the effects of the Reynolds number to the convergence histories with $\Delta t u_{0} / D$ of 0.05 . These figures indicate the optimal value for the artificial compressibility parameter $\beta$ is not affected by the Reynolds number.

Figure 3 shows the comparison of the time histories of $\operatorname{drag}(C d)$ and lift $(C l)$ coefficients with five different $\beta$ values at the Reynolds number of 500 and $\Delta t u_{0} / D$ of 0.01 , as one can see the differences among the results are negligible. Instantaneous pressure distributions, not shown in this article, showed no major differences either. So it can be concluded that the size of the artificial

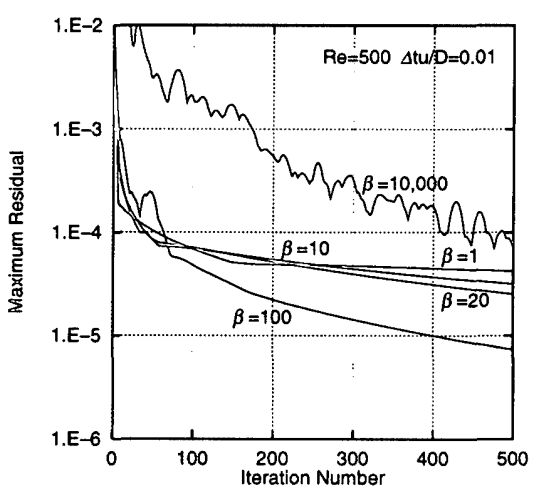

2a: $\operatorname{Re}=500 \Delta t u_{0} / D=0.01$

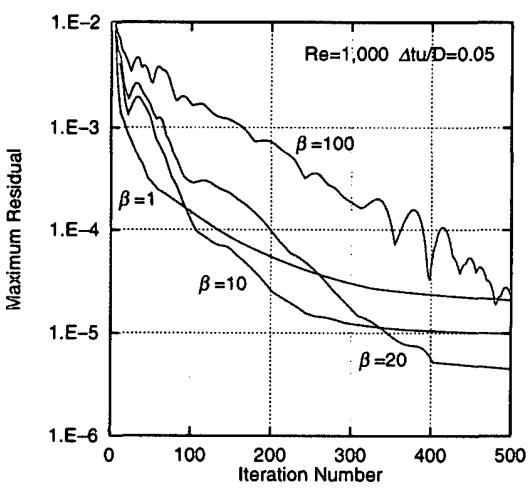

2d: $\operatorname{Re}=1,000 \Delta t u_{0} / D=0.05$

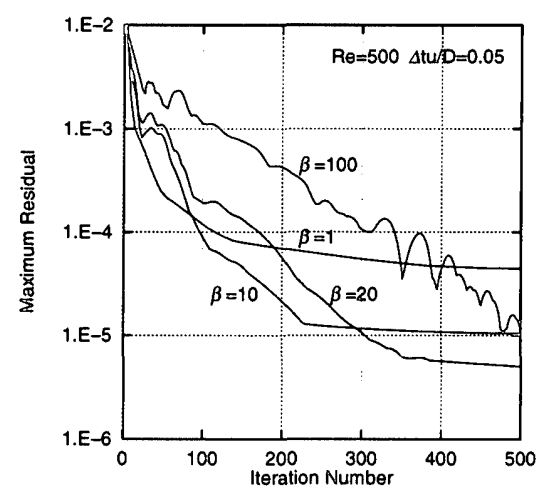

2b: $\operatorname{Re}=500 \Delta t u_{0} / D=0.05$

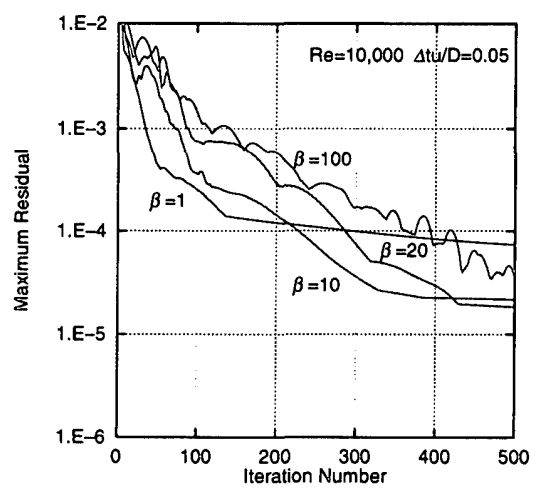

2e: $\operatorname{Re}=10,000 \Delta t u_{0} / D=0.05$

Figure 2 Maximum residual vs. pseudo-time iteration number or the flow around a circular cylinder

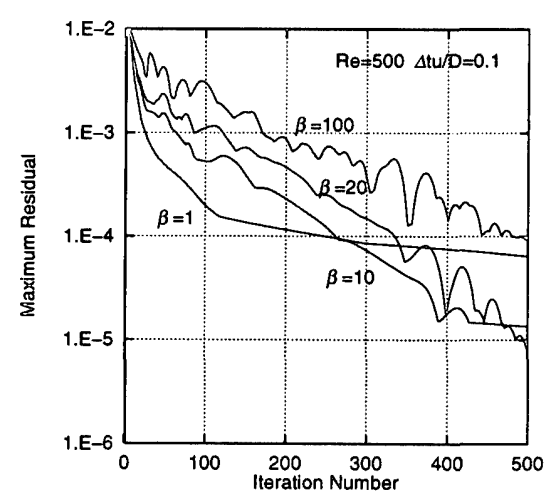

2c : $\operatorname{Re}=500 \quad \Delta t u_{0} / D=0.1$

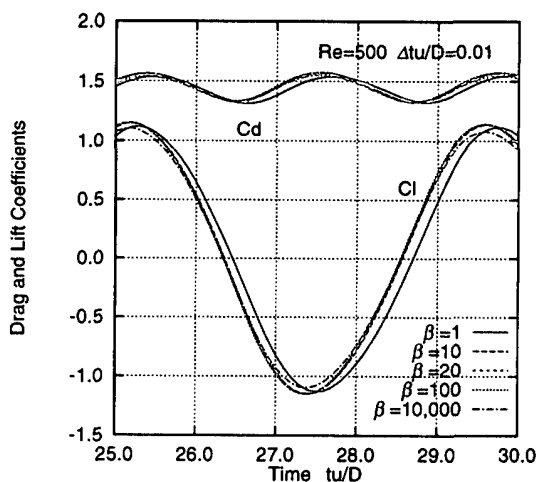

Figure 3 Lift and drag coefficients vs. time $\operatorname{Re}=500 \Delta t u_{0} / D=0.01$ 
compressibility parameter dominates the speed of convergence but has no influence on flow fields.

Ohnishi et. al. ${ }^{9)}$ proposed an equation which links the artificial compressibility parameter, the step sizes for pseudo and physical time and the grid interval $\Delta x$ as shown in Equation (16). With simplifying $\Delta \tau=\Delta t$ and regarding the Courant number could be approximated as $\mathrm{CFL} \cong \Delta t / \Delta x(<1)$, they concluded that the optimal relation was $\beta \approx 1$.

Meanwhile with the present method, the pseudo-time step size is computed from the artificial speed of sound as $\Delta \tau \approx \Delta x / c$, therefore, with the definition of artificial speed of sound for the Cartesian coordinate $c=\sqrt{u^{2}+\beta}$, Equation (16) can be written as;

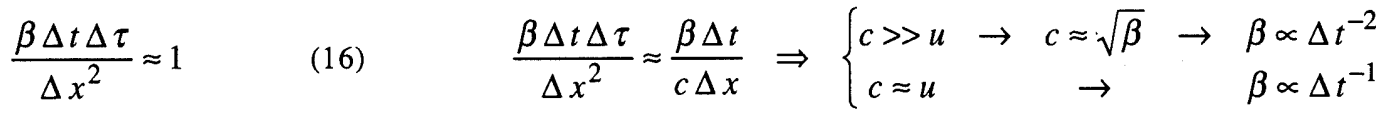

Equation (17) indicates two possible relations for the optimal vales. The relation of $\beta \propto \Delta t^{-2}$ requires a very large size of the artificial speed of sound, and leads to a very small pseudo-time step size. This may become suitable for the case when the flow field changes rapidly with the large pressure fluctuation. The results shown in Figures $2 a \sim 2 c$ support the other relation, so in the case of vortex shedding or separating flows, the optimal value for the artificial compressibility parameter can be defined as $\beta \propto \Delta t^{-1}$.

\section{Flow Computations over a Square Cylinder}

\subsection{Computational Conditions}

Table 1 Computational conditions

\begin{tabular}{l|ccccccccccccc}
\hline & Domain size & \multicolumn{8}{c}{ Number of grid point } & $\alpha$ & $\beta$ & $\Delta t u_{0} / D$ CFL Average & time
\end{tabular}

\begin{tabular}{l|llllllllll} 
case 3 & $20 \mathrm{D} \times 16 \mathrm{D} \times 2 \mathrm{D}$ & $1.0 \mathrm{D}$ & $.5 \mathrm{D}$ & $97 \times 25 \times 15$ & 86,235 & 0.5 & 50.0 & 0.01 & 2.5 & 81 \\
\hline
\end{tabular}

Figure 4 Schematic for computational domain and block diagram

The schematic of the computational domain is shown in Figure 4. As shown in the figure, the domain was divided into 5 blocks and an $\mathrm{O}$ type grid was allocated around a square cylinder. The authors generated three different grid systems for this domain, whose details are listed in Table 1. Case 1 and case 2 have the same grid point distribution around a cylinder while case 2 contains the larger upwind region and the finer spanwise grid spacing. The coarser grid system around a cylinder is provided for case 3 . The

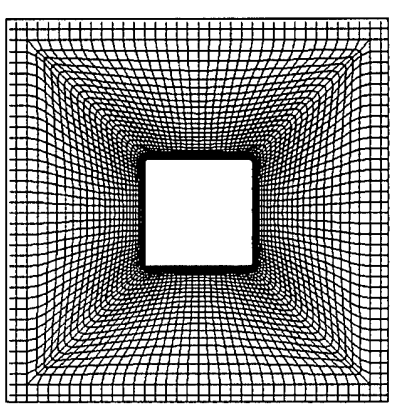

a: case 1

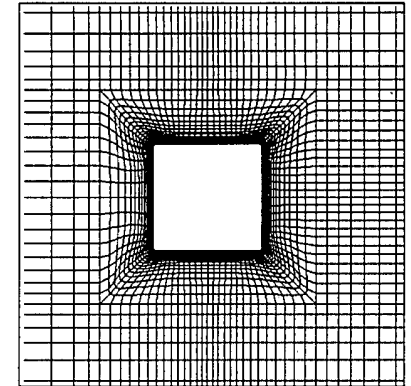

b: case 3

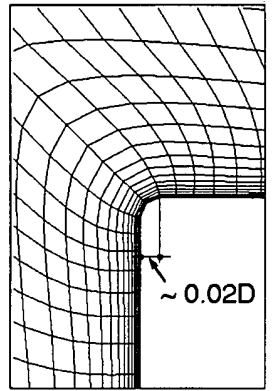

c: corner

Figure 5 Grid system around a rectangular cylinder spanwise length was kept as $2 D$ for all cases, where $D$ is the square cylinder diameter. In Figures $5 \mathrm{a}$ and $5 \mathrm{~b}$, the close views of the grids for cases 1 and 3 are shown. To avoid having skew grid lines at the corners, the corner's shape was modified as shown in Figure 5c. The distance between the body surface and the first interior grid point was kept as about $7.6 \times 10^{-4} \mathrm{D}$ while Murakami et al. ${ }^{12)}$ set as $2 \times 10^{-2} D$ in their computations. For all cases, Block 2 has 33 grid points in flow direction. Its grid stretchnig ratio ${ }^{17)}$ was set about $1.05(x / D<4)$ to $1.15(x / D>4)$ for case $1 \& 2$, and was kept constant as 1.08 for case 3 .

With using these grid systems, three-dimensional laminar flow computations at the Reynolds number 22,000 were conducted. The periodic boundary condition was set for the spanwise direction and the rest boundary conditions were set as those for the computations around a two-dimensional circular cylinder. The physical time derivatives are treated as a second-order implicit. Computational conditions such as the artificial compressibility parameter, the Courant number and the physical time step sizes are also listed in Table 1. The artificial dissipation parameter $\alpha$ was set as 0.5 . If $\alpha$ was set less than 0.5 , unphysical velocity oscillations at the windward corners were observed.

Two-dimensional flow computations preceded three-dimensional ones. Then the results of $2 \mathrm{D}$ computations were used as initial flow conditions of 3D. To get statistical values, the computations were lasted for the certain time period which is listed in Table 1.

\section{$\underline{5.2 \text { Velocity Field }}$}

Figure 6 compares the time averaged stream wise velocity $\left\langle u / u_{0}\right\rangle$ distributions along the symmetry line from present computations, Murakami's LES computation ${ }^{12}$ ) based on the dynamic mixed SGS model and Lyn's experimental data ${ }^{10)}$. In the wake flow, 


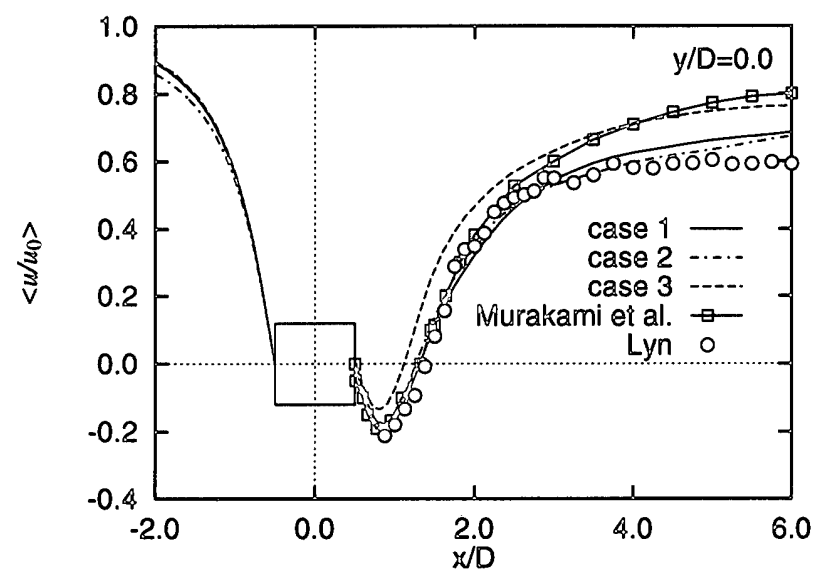

Figure 6 Comparison of the time averaged stream wise velocity distributions along the symmetry line
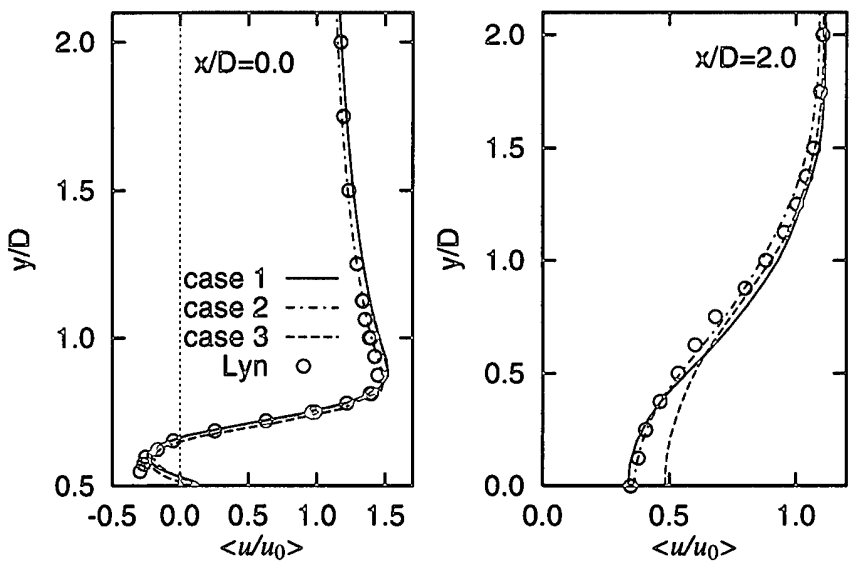

Figure 7 Comparison of the time averaged stream wise velocity profiles at $x / D=0.0$ and $x / D=2.0$

case 1 2 and Murakami's results show a very good agreement with the experimental data while case 3 underestimates the size of recirculation. At the end of experimental recirculation zone $(x / D=1.4)$, case 1 and 2 have the streamwise grid size of about $0.09 D$, whereas case 3 has that of $0.13 D$. This coarser grid system of case 3 brought the larger numerical dissipation and could have caused discrepancy. At the far wake region $(x / D>4)$, case 1 and 2 start to differ from the experimental data but their differences are smaller than Murakami's one. In Figure 7, the time averaged velocity profiles at $x / D=0$ and $x / D=2$ are compared with the experimental data. At $x / D=0$, the differences among computed results and experimental data are nominal and the precise location of velocity shear layer is captured by the present method. Case 1 and 2 show identical velocity profile as experimental data at $x / D=2$.

It must be argued why present laminar computations show the same accuracy as Murakami's LES computation. The most distin-

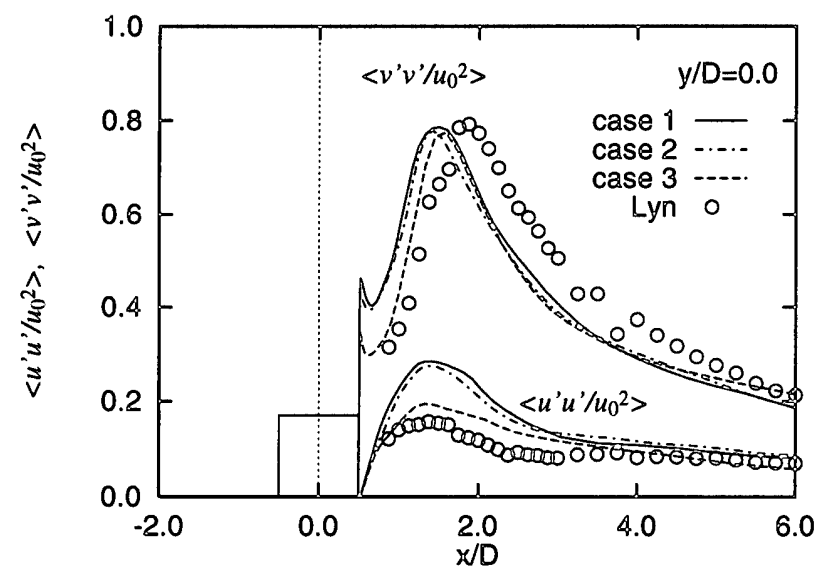

Figure 8 Comparison of the Reynolds stresses along the symmetry line
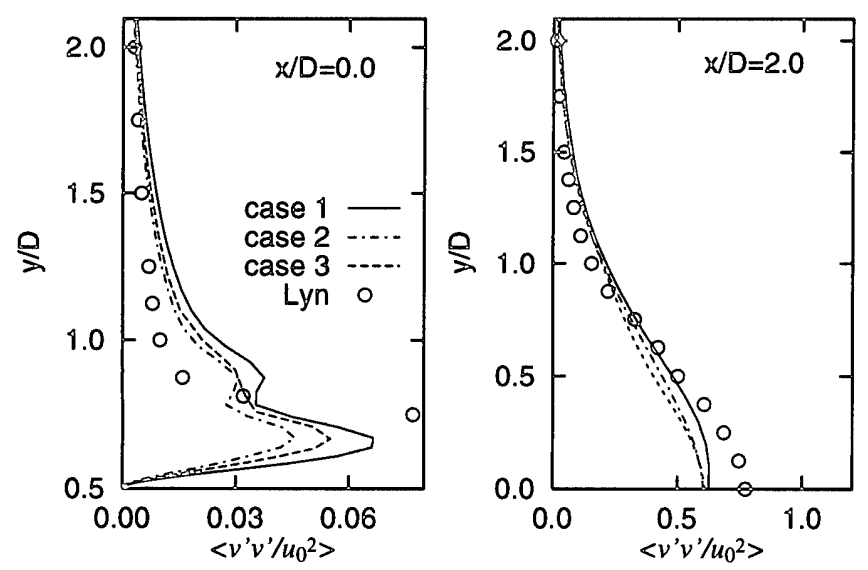

Figure 9b: Comparison of the Reynolds stress $\left\langle v^{\prime} v^{\prime} / u_{0}^{2}\right\rangle$ profiles at $x / D=0.0$ and $x / D=2.0$
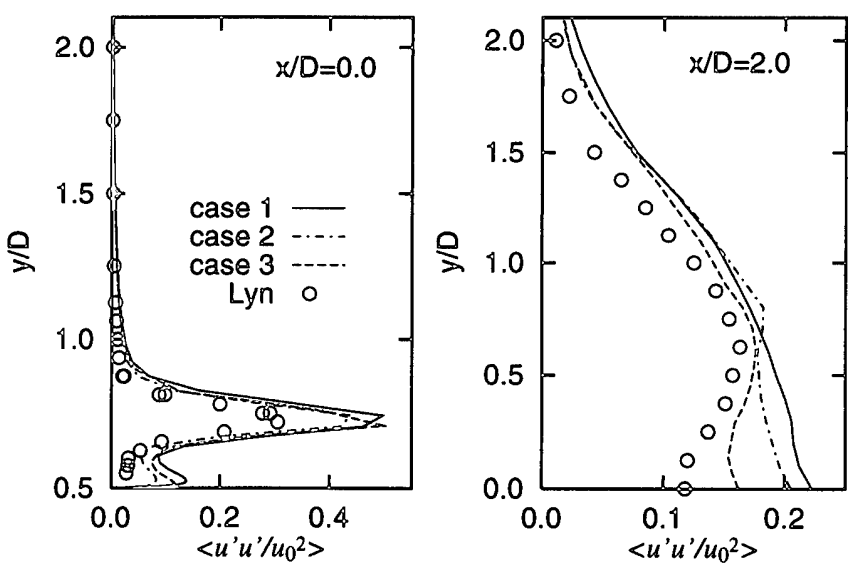

Figure 9a: Comparison of the Reynolds stress $\left\langle u^{\prime} u^{\prime} / u_{0}^{2}\right\rangle$ profiles at $x / D=0.0$ and $x / D=2.0$
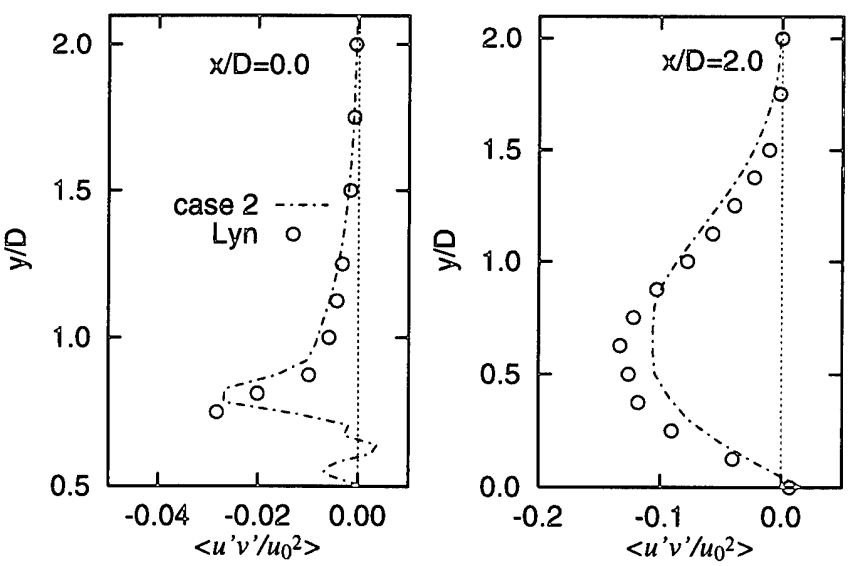

Figure 9c: Comparison of the Reynolds stress $\left\langle u^{\prime} v^{\prime} / u_{0}^{2}\right\rangle$ profiles at $x / D=0.0$ and $x / D=2.0$ 
guishable difference among authors' computations and Murakami's one is the grid resolution. The grid systems for case 1 and 2 may have the sufficient spatial resolution for capturing those eddies which are essential to the flow around a square cylinder at the Reynolds number of 22,000 , although they are too coarse for conducting the "direct" computations of turbulent flows.

\subsection{Reynolds Stresses}

Figure 8 shows the distribution of the Reynolds stresses along the symmetry line. The computed results of $\left\langle u^{\prime} u^{\prime} / u_{0}{ }^{2}\right\rangle$ become larger than experimental data. For the $\left\langle v^{\prime} v^{\prime} / u_{0}^{2}\right\rangle$ distributions, the computed peak values are almost the same as experiments while the computed peaks occur slightly windward position of the experimental peak. In Figure 9, the Reynolds stress profiles at $x / D=0$ and $x / D=2$ are compared with the experimental data. The shear stress $\left\langle u^{\prime} v^{\prime} / u_{0}{ }^{2}\right\rangle$ was computed with case 2 only. Unlike the excellent agreement of $\left\langle u / u_{0}\right\rangle$ distributions, the agreement of the computed Reynolds stresses with the experiment is moderate.

\subsection{Pressure Field}

Figure 10 shows the distribution of the time averaged pressure coefficient on the surface of the square cylinder. Since Lyn ${ }^{10)}$ provided no pressure distributions, present results are compared with the experimental data from Ohtsuki et. al ${ }^{18)}$. On the windward surface, the present computations overestimate (e.g. 1.17 for case 2's peak). This discrepancy can be explained as follows; The lateral domain size of $16 \mathrm{D}$ is not enough to prevent the blockage effect and causes an additional pressure gradient within flow direction. Since computations set the pressure value at the outflow boundary as the reference, the inflow pressure value

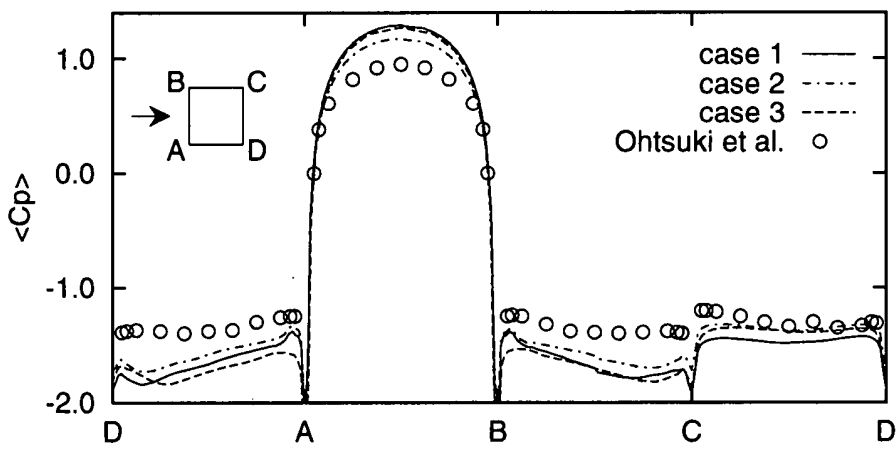

Figure 10 Distribution of the time averaged pressure coefficient was shifted from it (e.g. 0.16 for case 2). Therefore the computed surface pressure coeffcients are also shifted.

Table 2 Comparison of Strouhal number $S_{t}$, and aerodynamic forces $\mathrm{Cd}, \mathrm{Cd}^{\prime}$ and $\mathrm{Cl}^{\prime}$

Present results of Strouhal numbers $S_{t}$, drag coefficients $C d$, RMS values of drag coefficients $C d^{\prime}$ and RMS values of lift coefficients $C l^{\prime}$ are listed in Table 2, and compared with Lyn's experimental data which is cited from Murakami's list ${ }^{12)}$

\section{Conclusions}

\begin{tabular}{l|cccc}
\hline & $S_{t}$ & $C d$ & $C d^{\prime}$ & $C l^{\prime}$ \\
\hline case 1 & 0.128 & 2.34 & 0.40 & 1.47 \\
case 2 & 0.133 & 2.13 & 0.33 & 1.38 \\
case 3 & 0.132 & 2.20 & 0.29 & 1.47 \\
Exp.(Lyn) & 0.132 & 2.1 & - & - \\
\hline
\end{tabular}

An algorithm based on the artificial compressibility method is tested for the computation of separating flow around a body. The basic equations are transformed into a generalized coordinate system and discretized with a finite volume method. A third-order upwind differencing scheme is used to compute convective terms and a fourth-order damping term is added to the pressure equation to avoid unphysical oscillations. The optimal parameter values are examined through a series of two-dimensional laminar flow computations over a circular cylinder. The results indicate the optimal value for the artificial compressibility parameter can be decided with the physical time step size. Then three dimensional flow computations around a square cylinder at the Reynolds number 22,000 are presented and the results are compared with experimental and other computational results. Though present computations are laminar, the computed profiles of the time averaged velocity show better agreement with the experimental data, and its accuracy is in the same level as other's LES computation. The computed Reynolds stresses show moderate coincidence with the experiments. It is proved that the artificial compressibility method can predict the separating flow when it is used with a multiblock flow solver.

\section{References}

1) Harlow, F. H. and Welch, J. E. : Numerical calculation of time-dependent viscous incompressible flow with free surface, Physics of Fluids, Vol. 8, pp. 2182-2189, 1965

2) Hirt, C. W., Nichols, B. D. and Romero, N. C. : SOLA-a numerical solution algorithm for transient fluid flows, Los Alamos Scientific Laboratory Rep. LA-5852, 1975

3) Patanker, S. V. and Spalding, D. B. : A calculation procedure for heat, mass and momentum transfer in three-dimensional parabolic flows, Int. J. Heat and Mass Transfer, Vol. 15, pp. 1787-1806, 1972.

4) Suwa, Y., Fujii, S., Yuasa, K. and Sano, H. : Airflow simulation around buildings using overset grid coordinate system - a development of calculation algorithm and studies on its performance - (in Japanese), J. Archit. Plann. Environ. Eng., Trans. AIJ, No. 488, pp. 43-52, 1996.

5) Kataoka, H. and Mizuno, M. : Numerical method of multiblock computation for flow around complex building, J. Archit. Plann. Environ. Eng., Trans. AIJ, No. 495, pp. 53-60, 1997.

6) Chorin, A. J. : A numerical method for solving incompressible viscous flow problems, J. Comp. Physics, Vol. 2, pp. 12-26, 1967.

7) Rogers, S. E. and Kwak, D. : Upwind differencing scheme for the time-accurate incompressible Navier-Stokes equations, AIAA J., Vol. 28, pp. 253-262, 1990

8) Rogers, S. E., Kwak, D. and Kiris, C. : Steady and unsteady solutions of the incompressible Navier-Stokes equations, AIAA J., Vol. 29, pp. 603-610, 
1991.

9) Ohnishi, T., Miyake, Y. and Kinoshita, K. : Unsteady flow simulation of a two-dimensional thin arc airfoil using pseudocompressibility method (in Japanese), Trans. JSME, Vol. 61, No. 591 B, pp. 71-77, 1995

10) Lyn, D. A. and Rodi, W. : The flapping shear layer formed by flow separation from the forward corner of a square cylinder, J. Fluid Mech., Vol. 267, pp. 353-376, 1994. (or WWW ERCOFTAC DATABASE, http://fluindigo.mech.surrey.ac.uk)

11) Murakami, S. and Mochida, A. : On turbulent vortex shedding flow past 2D square cylinder predicted by CFD, J. Wind Eng. Industrial Aerodynamics, Vol. 54/55, pp. 191-211, 1995.

12) Murakami, S., Iizuka, S., Mochida, A. and Tominaga, Y. : LES analysis on turbulent flow past 2D square cylinder using various dynamic SGS models, Seisan-Kenkyu, Vol. 49, No. 1, pp. 39-45, 1997

13) Ferziger, J. : Simulation of complex turbulent flows: recent advances and prospects in wind engineering, J. Wind Eng. Industrial Aerodynamics, Vol. 46/47, pp. 195-212, 1993

14) Kawamura, T. and Kuwahara, K. : Computation of high Reynolds number flow around a circular cylinder with surface roughness, AIAA paper 84$0340,1984$.

15) Leonard, B. P. : A survey of finite differences with upwinding for numerical modeling of the incompressible convective diffusion equation, Computational Techniques in Transient and Turbulent Flow, Vol. 2, Pineridge Press, 1981.

16) Jameson, A. : Solution of the Euler equations for two dimensional transonic flow by a multigrid method, Applied Mathematics and Computation, Vol. 13 , pp. 327-355, 1983.

17) Iizuka, S., Murakami, S. and Mochida, A. : LES of flow past 2D square cylinder - effect of grid stretching ratio on prediction accuracy - (in Japanese), J. of Wind Eng. No. 71, pp.191-192, 1997.

18) Ohtsuki, Y, et al. : Wind tunnel experiments on aerodynamic forces and pressure distributions of rectangular cylinders in a uniform flow, Proc. 5th Symp. on Wind Effects on Structures, pp. 169-175, 1978.

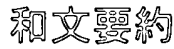

\section{1.はじ的に}

建築構造物周りのように鈍い物体周りの剥離を伴う流れ場は、物 体の形状と周辺圧力分布によって支配される。従って、建物周りの 剥離流れを扱う場合、压力場の予測精度と䊗造物周辺の格子解像度 の両方が重要である。これに対して既報では、領域分割法の一つで あるマルチブロック法と擬似圧縮性法との組み合わせを提案した。

本報では、まず擬似圧縮性法特有の各擬似圧縮性パラメー夕の最 適値について考察し、次にレイノルズ数 22,000における正方形角柱 周りの気流解析を行う。既往の実験データならびに計算結果との比 較を通して、擬似圧縮性法とマルチブロック法の組み合わせによる 剥離を伴う流れ場の予測精度を検証する。ただし乱流モデルを使用 せず、数值粘性の影響を極力取り除いた層流計算を行うものとする。

\section{2. 琶经起}

擬似圧縮性法の基磁式は、連続の式に圧力の擬似時間微分項を加 えたものと、運動方程式に速度の擬似時間微分項を加えたものから なる。これら基稳式を一般座標系を用いて表わした。

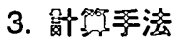

上記の基䟖式を有限体積法を用いて離散化する。対流項は四次の 中心差分に四次の数値粘性項を付加することで風上化を行う。また 圧力式にも同様に四次の数值粘性項を付加する。

時間微分項は、擬似時間に関しては陽的に物理時間は陰的に扱う。 擬似時間刻みの値は、擬似圧縮性を萃入したことで生じる擬似音速 の値を用いて、各格子点毎に異なる値を与えることとした。

流入流出境界条件として特性の方法を用いる。

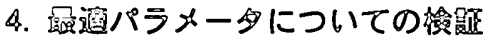

一連の円柱周りの二次元気流計算を行い、擬似圧縮性パラメータ の違いによる計算の収束に与える影響を調べた。収束が早くなる最
適値は、物理時間刻みの大きさによって変化し、レイノルズ数を変 えてもその傾向は変わらなかった。また、非定常空気力の時刻歷の 比較から、擬似圧縮性パラメー夕の值は解の収束性には影裂あるも のの、流れ場には影瑤を及ぼさない事が判明した。さらに既往の考 察を基に、最適な擬似圧縮性パラメータの値と物理時間刻みの関倸 について検钨を行った。

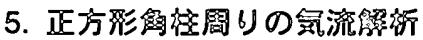

レイノルズ数22,000における正方形角柱周りの三次元気流解析を、 乱流モデルを用いずに行った。対流項における数值粘性の影桴を除 去するために、同項にかかる係数を1/2(UTOPIA スキームの半分) と し、物理時間微分に関しては二次精度とした。また角柱周りの格子 解像度の異なる三つの格子を用いて計算を行った。

その結果、最も粗い格子を用いた場合を除いて、時間平均速度分 布、特に角柱風下の逆流領域の大きさがLynの実験結果ならびに村上 らによるLES計算結果と良く一致した。乱流モデルを用いない本計 算によるこの一致は、角柱周りで生じる剥離流れの基本的な檴造を 捉えるだけの十分な格子解像度があった為と考える。さらにレイノ ルズ応力分布の計算結果も実駼結果との比較的良い一致がみられた。

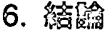

擬似圧縮性法を用いた物体周りの剥離流れの解析を行った。一連 の円柱周りの二次元気流解析により、擬似圧縮パラメータの最適値 は物理時間刻みと関連付けらることを明らかにした。また正方形角 柱周りの三次元気流解析を行い、既往の実験結果や計算結界との比 較的良い一致がみられた。これにより、擬似圧縮性法とマルチブロ ック法を組み合わせて用いることで、物体周りの剥離流れが精度良 く捉えられることが示された。ただしこれらの解析は本解析手法の 検証を目的として行われたものであって、乱流モデルの使用を否定 するものではない事を付記する。 